${ }^{7}$ Atkins, H, et al, British Medical fournal, 1972, 2, 423.

8 Dao, T L, and Nemoto, T, Surgery, Gynecology and Obstetrics, 1963, 117, 447.

9 Carter, R L, in Secondary Spread in Breast Cancer, ed Basil A Stoll, p 31. London, Heinemann Medical, 1977. •

${ }^{10} \mathrm{Chu}$, Florence C H, in Breast Cancer Management, Early and Late, ed Basil A Stoll, p 101. London, Heinemann Medical, 1977.

11 Peto, R, et al, British fournal of Cancer, 1976, 34, 585 and 1977, 35, 1.

12 Paterson, R, and Russell, M J, Fournal of the Faculty of Radiologists, 1959, $10,175$.

${ }^{13}$ Fisher, B, et al, Annals of Surgery, 1970, 172, 711.
${ }_{14}$ McDonald, A M, Simpson, J S, and MacIntyre, I, Lancet, 1976, 1, 1098.

${ }_{15}$ Herrell, W E, American fournal of Cancer, 1937, 29, 659.

${ }_{16}$ Dargent, M, British Medical fournal, 1949, 2, 54

17 Smithers, D W, et al, British fournal of Radiology, suppl No 4, 1952.

18 MacMahon, B, List, N D, and Eisenberg, H, in Prognostic Factors in Breast Cancer, ed A P M Forrest and P B Kunkler, p 56. Edinburgh, Livingstone, 1968.

19 Fisher, B, et al, New England fournal of Medicine, 1975, 292, 117.

${ }^{20}$ Bonadonna, G, et al, New England fournal of Medicine, 1976, 294, 405.

\title{
Ventricular tachycardia due to cardiac ischaemia: assessment by exercise electrocardiography
}

\author{
STEPHEN TALBOT, DAVID KILPATRICK, DENNIS KRIKLER, CELIA M OAKLEY
}

British Medical fournal, 1978, 2, 733-736

\section{Summary and conclusions}

Although ventricular tachycardia is a well-known complication of myocardial ischaemia and may be provoked by exercise, many patients may appreciate only the angina and be unaware of the unduly rapid heart rate that precipitates it. Exercise testing is needed to show this arrhythmia and to enable treatment to be started.

Twenty-three patients were found to have chronic ischaemic heart disease complicated by ventricular tachycardia. Six patients with old myocardial infarction had ventricular tachycardia at rest which required conversion to sinus rhythm; 17 patients developed ventricular tachycardia only when they exercised. In 12 of these 17 patients coronary angiography showed disease of the anterior descending branch of the left coronary artery; other vessels were usually also affected. Although beta-adrenergic blocking drugs increased exercise tolerance, ventricular tachycardia still occurred when the heart rate on exercise reached a level similar to that before treatment. In five patients coronary artery bypass surgery was performed because of angina and exercise-induced ventricular tachycardia. Exercise tolerance was increased in all three patients who underwent exercise tests after operation, and in two of these patients, both of whom were known to have patent grafts, ventricular tachycardia was abolished.

If part of the beneficial effect of coronary bypass surgery is preventing life-threatening ventricular arrhythmias it is essential to detect these, and ambulatory monitoring and stress testing have a complementary role.

\section{Introduction}

In patients with coronary artery disease ventricular arrhythmias are often induced by exercise. ${ }^{1}$ They may also occur at rest. ${ }^{2}{ }^{3}$

\footnotetext{
Division of Cardiovascular Disease, Royal Postgraduate Medical School, Hammersmith Hospital, London W12 0HS STEPHEN TALBOT, MB, MRCP, senior registrar DAVID KILPATRICK, MB, BSC, research fellow DENNIS KRIKLER, MD, FRCP, consultant cardiologist CELIA M OAKLEY, MD, FRCP, consultant cardiologis
}

The clinical importance of ventricular extrasystoles and the "warning arrhythmias" is uncertain, ${ }^{4}$ but ventricular tachycardia must be treated, whether with beta-blocking drugs, membrane stabilising drugs like quinidine, or coronary artery bypass surgery. We have studied ventricular tachycardia at rest and on exercise in patients with cardiac ischaemia to determine the clinical features, treatment and prognosis, and the effects of beta-blockade and coronary artery bypass surgery.

\section{Patients and methods}

Two groups of patients were identified clinically.

Group 1 comprised six patients with chronic ischaemic heart disease who had been admitted with sustained ventricular tachycardia (lasting for a minute or more) that necessitated medical or electrical conversion. All underwent exercise while on prophylactic treatment that had either abolished or diminished the frequency and severity of attacks at rest.

Group 2 consisted of 870 patients with suspected ischaemic heart disease who underwent a modified Bruce treadmill exercise test for diagnosis of ischaemia and evaluation of exercise tolerance. ${ }^{5}$ Informed consent was obtained from all patients before discontinuing any treatment and performing the test. The Frank orthogonal 3-lead system was used and all tests were performed by at least one doctor and a technician. Patients were encouraged to exercise until they suffered angina, fatigue, or dyspnoea. Exercise was stopped promptly when ventricular tachycardia or successive or multiform ventricular extrasystoles occurred. Simultaneous X, Y, and Z leads of the electrocardiogram were recorded conventionally on paper and on electromagnetic tape, and the heart rate and rhythm were monitored and S-T segment displacement observed. Ventricular tachycardia was diagnosed when three or more ventricular extrasystoles in a row (separated on average by $\leqslant 600 \mathrm{~ms}$ ) occurred. Whenever possible patients who developed ventricular tachycardia on or after exercise were exercised again while on treatment.

Coronary arteriography and left ventricular angiography were performed by the femoral percutaneous technique. ${ }^{6}$ All patients were followed up for at least three months after the last therapeutic intervention.

\section{Results}

Altogether 870 patients performed treadmill exercise tests, and ventricular arrhythmias were recorded in 144 during or after exercise. Ventricular tachycardia was found in 33 of these patients, 17 of whom had ischaemic heart disease. Of these 17, 12 had lesions on coronary arteriography; two had electrocardiographic evidence of anterior myocardial infarction as well as significant $\mathrm{S}-\mathrm{T}$ segment depression $(\geqslant 0.2 \mathrm{mV})$ with angina after exercise; and three had S-T changes during and after exercise that suggested ischaemia. Ventricular tachycardia had been suspected in only two patients before exercise testing. 
During the same period six patients with previous myocardial infarction presented with sustained uniform ventricular tachycardia necessitating conversion to sinus rhythm; three of the four with anterior myocardial infarction had left ventricular aneurysms. Medical treatment with quinidine or dysopyramide reduced the frequency and duration of attacks of ventricular tachycardia in four patients and abolished them in two. Ventricular tachycardia could not be precipitated by exercise while the patients were on this treatment.

Table I summarises the results for the patients with ventricular tachycardia on or after exercise (group 2). Only one patient had a clearcut history of palpitations with evidence of ventricular tachycardia, but three patients had had dizziness or syncope on exercise without preceding angina. Angina never preceded the ventricular tachycardia but occurred together with or after it in six patients. In two patients ventricular tachycardia occurred only after exercise; in two others it was more prolonged after exercise. All 12 patients who underwent coronary arteriography had disease of the left anterior descending coronary artery and in 10 there was $50 \%$ or greater narrowing of this vessel. Three developed ventricular fibrillation: this occurred during exercise testing in one, in whom defibrillation was successful; in another successful defibrillation was performed at another hospital; and the third died suddenly at home despite treatment with oxprenolol $80 \mathrm{mg}$ three times a day. In three patients ambulatory monitoring failed to show ventricular tachycardia, although single ventricular extrasystoles were seen in two patients.

The results of the exercise tests are shown in table II. Treadmill exercise testing was repeated on increasing doses of beta-blocking drugs in nine patients. In six patients exercise tolerance was improved and in four ventricular tachycardia did not recur, but the heart rates of these patients did not rise to the levels that had been associated with the onset of ventricular tachycardia before treatment. One patient on propranolol $160 \mathrm{mg}$ three times a day developed ventricular tachycardia with a similar exercise tolerance and heart rate to those before treatment; in one other patient exercise was stopped earlier after treatment at a lower heart rate because of double ventricular extrasystoles (case 8); one patient had ventricular tachycardia at rest on oxprenolol, but his exercise tolerance was severely limited because of ventricular tachycardia at other times, despite a wide variety of antiarrhythmic drugs.

\section{Case reports}

Case 1-A 55-year-old woman had a three-month history of angina at rest and on exercise. Initially there was no ventricular tachycardia on a limited exercise test. Coronary arteriography showed $80 \%$ stenosis of the proximal left anterior descending coronary artery with lesser disease of the proximal circumflex and right coronary arteries. Neither propranolol $120 \mathrm{mg} /$ day nor oxprenolol $480 \mathrm{mg} /$ day prevented angina. Nine months later exercise testing was repeated because of increasing angina, and multiform ventricular tachycardia occurred during and after exercise, with a maximum sinus rate of 140 beats/min and an identical exercise tolerance (fig 1). Ventricular tachycardia was not controlled with oxprenolol in a dose of $160 \mathrm{mg}$ three times a day. Coronary arteriography was repeated and showed no change. After bypass of the left anterior descending coronary artery she had no further episodes during or after exertion while the exercise tolerance and the maximum heart rate were increased. Angiography two years later showed a patent venous graft and no change in the extent of the coronary artery disease.

Case 10-A 71-year-old man experienced mild angina on exertion. He exercised twice to the same degree and heart rate $(150$ beats $/ \mathrm{min})$ and developed ventricular tachycardia at peak exercise. Treatment with verapamil prevented ventricular tachycardia only at a dose of $120 \mathrm{mg}$ three times a day when exercise tolerance was prolonged to $5 \frac{1}{2}$ minutes with a maximum heart rate of 120 beats/min; a similar response was observed with propranolol $40 \mathrm{mg}$ three times a day. The patient remained well on this treatment one year later.

Surgery-Five patients underwent coronary artery surgery (including case 1). Subsequent exercise testing in two patients showed abolition of ventricula

TABLE I-Details of patients who had ventricular tachycardia on exercise testing

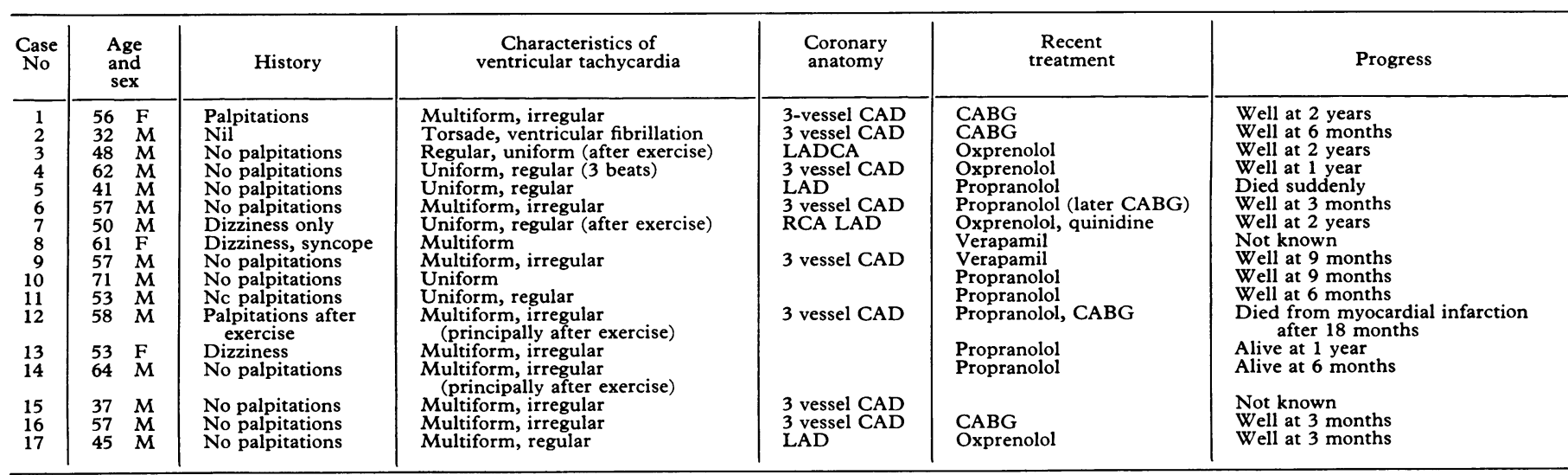

$\mathrm{CAD}=$ Coronary artery disease. $\quad$ LADCA $=$ Left anterior descending coronary artery. $\mathrm{RCA}=$ Right coronary artery. CABG $=$ Coronary artery bypass grafting.

TABLE II-Results of exercise testing before and during treatment (group 2 )

\begin{tabular}{|c|c|c|c|c|c|c|c|}
\hline \multirow{2}{*}{ Patient } & \multicolumn{2}{|c|}{ Before treatment } & \multirow{2}{*}{$\begin{array}{l}\text { Exercise testing } \\
\text { rate of ventricular } \\
\text { tachycardia }\end{array}$} & \multirow{2}{*}{ Treatment } & \multicolumn{2}{|c|}{ During treatment } & \multirow{2}{*}{$\begin{array}{c}\text { Rate of } \\
\text { ventricular tachycardia } \\
\text { (VT) }\end{array}$} \\
\hline & $\begin{array}{c}\text { Exercise } \\
\text { tolerance }\end{array}$ & $\begin{array}{c}\text { Maximal } \\
\text { heart rate }\end{array}$ & & & $\begin{array}{l}\text { Exercise } \\
\text { tolerance }\end{array}$ & $\begin{array}{l}\text { Maximal } \\
\text { heart rate }\end{array}$ & \\
\hline $\begin{array}{l}1 \\
2 \\
3 \\
4 \\
5 \\
6\end{array}$ & $\begin{array}{l}5 \min 30 \mathrm{~s} \\
4 \min 30 \mathrm{~s} \\
3 \mathrm{~min} 30 \mathrm{~s} \\
7 \mathrm{~min} 30 \mathrm{~s} \\
3 \mathrm{~min} 30 \mathrm{~s} \\
5 \mathrm{~min}\end{array}$ & $\begin{array}{l}110 / \min \\
160 \mathrm{~min} \\
160 / \mathrm{min} \\
140 / \min \\
120 / \min \\
120 / \mathrm{min}\end{array}$ & $\begin{array}{r}140 / \mathrm{min} \\
180 \mathrm{~min} \\
>200 / \mathrm{min} \\
200 / \mathrm{min} \\
150 / \mathrm{min} \\
180 / \mathrm{min}\end{array}$ & $\begin{array}{l}\text { CABG } \\
\text { None } \\
\text { Oxprenolol } 80 \mathrm{mg} \text { tds } \\
\text { Oxprenolol } 120 \mathrm{mg} \text { tds } \\
\text { Propranolol } 160 \mathrm{mg} \text { tds } \\
\text { CABG }\end{array}$ & $\begin{array}{l}9 \min 30 s \\
6 \min 30 s \\
4 \min 15 s \\
6 \min 30 s\end{array}$ & $\begin{array}{l}150 / \min \\
160 / \min \\
120 / \min \\
145 / \min \end{array}$ & $\begin{array}{l}\text { Nil } \\
\text { VT } 200 / \mathrm{min} \text {, ventricular fibrillation } \\
\text { VT } 150 / \text { min } \\
\text { Double ventricular extrasystole } \\
\text { after exercise only }\end{array}$ \\
\hline $\begin{array}{r}7 \\
8 \\
9 \\
10 \\
11 \\
12\end{array}$ & $\begin{array}{l}6 \mathrm{~min} \\
2 \min 15 \mathrm{~s} \\
4 \mathrm{~min} 30 \mathrm{~s} \\
4 \mathrm{~min} 30 \mathrm{~s} \\
4 \mathrm{~min} \\
1 \mathrm{~min}\end{array}$ & $\begin{array}{l}120 / \min \\
100 / \mathrm{min} \\
155 / \mathrm{min} \\
150 / \mathrm{min} \\
160 / \mathrm{min} \\
120 / \mathrm{min}\end{array}$ & $\begin{array}{l}150 / \min \\
180 / \mathrm{min} \\
150-160 / \mathrm{min} \\
150 / \mathrm{min} \\
170 / \mathrm{min} \\
150 / \mathrm{min}\end{array}$ & $\begin{array}{l}\text { Oxprenolol } 80 \mathrm{mg} \text { tds } \\
\text { Propranolol } 40 \mathrm{mg} \text { tds } \\
\text { Verapamil } 80 \mathrm{mg} \text { tds } \\
\text { Propranolol } 40 \mathrm{mg} \mathrm{tds} \\
\text { Propranolol } 80 \mathrm{mg} \text { tds } \\
\text { Oxprenolol } 120 \mathrm{mg} \text { tds }\end{array}$ & $\begin{array}{l}5 \min 30 \mathrm{~s} \\
5 \min 45 \mathrm{~s} \\
5 \min 15 \mathrm{~s}\end{array}$ & $\begin{array}{l}120 / \mathrm{min} \\
120 / \mathrm{min} \\
140 / \mathrm{min} \\
64 / \mathrm{min}\end{array}$ & $\begin{array}{l}\text { VT after exercise } 160 / \mathrm{min} \\
\text { No VT } \\
\text { No VT } \\
\text { VT at rest }\end{array}$ \\
\hline $\begin{array}{l}13 \\
14\end{array}$ & $\begin{array}{l}5 \min 15 \mathrm{~s} \\
3 \mathrm{~min}\end{array}$ & $\begin{array}{l}150 / \mathrm{min} \\
145 / \mathrm{min}\end{array}$ & $\begin{array}{l}160 / \mathrm{min} \\
150 / \mathrm{min}\end{array}$ & $\begin{array}{l}\text { Propranolol } 40 \mathrm{mg} \text { tas } \\
\text { Propranolol } 40 \mathrm{mg} \text { tds }\end{array}$ & $5 \min 05 \mathrm{~s}$ & $140 / \mathrm{min}$ & $\begin{array}{l}\text { Double ventricular extrasystole } \\
\text { at peak exercise and after } \\
\text { exercise }\end{array}$ \\
\hline $\begin{array}{l}15 \\
16 \\
17\end{array}$ & $\begin{array}{l}5 \min 10 \mathrm{~s} \\
3 \mathrm{~min} 35 \mathrm{~s} \\
3 \mathrm{~min} 30 \mathrm{~s}\end{array}$ & $\begin{array}{l}155 / \mathrm{min} \\
100 / \mathrm{min} \\
145 / \mathrm{min}\end{array}$ & $\begin{array}{l}160 / \mathrm{min} \\
170 / \mathrm{min} \\
150 / \mathrm{min}\end{array}$ & $\begin{array}{l}\text { CABG } \\
\text { Oxprenolol } 40 \mathrm{mg} \text { tds }\end{array}$ & $4 \mathrm{~min} 30 \mathrm{~s}$ & $140 / \mathrm{min}$ & No VT \\
\hline
\end{tabular}

CABG $=$ Coronary artery bypass grafting. 
tachycardia despite increased exercise tolerance in one patient (case 6), in whom all three grafts were patent three months after operation; ventricular tachycardia still occurred at peak exercise in the other patient (case 12), but grafting was unsatisfactory, and myocardial infarction occurred after operation.

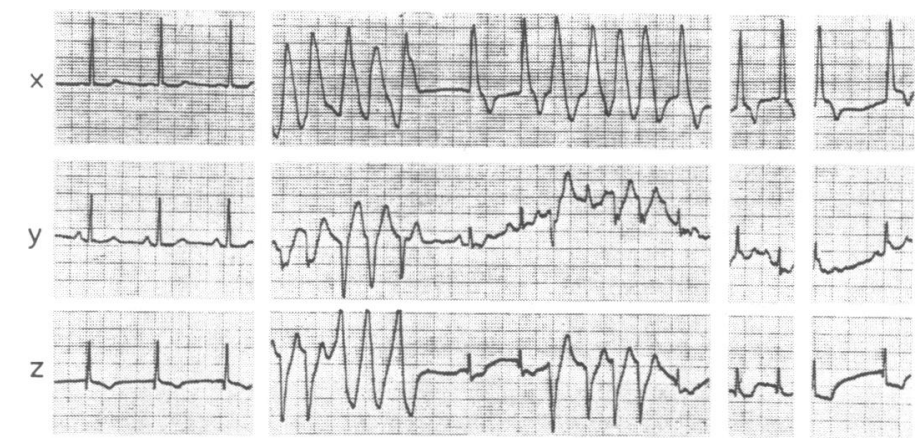

FIG 1-Case 1. Left: resting electrocardiogram; centre: multiform ventricular tachycardia at peak exercise together with nonspecific intraventricular block; right: immediately after exercise and one minute after exercise QRS still remains abnormal with $S-T$ depression in lead $Z$ and $S-T$ elevation in lead X.

\section{Discussion}

These results suggest that chronic ischaemic heart disease is an important cause of ventricular tachycardia during or immediately after treadmill exercise. Ventricular tachycardia is reproducible on treadmill exercise testing, although less malignant forms of ventricular arrhythmias are not so reproducible. ${ }^{7}$ All patients with ischaemic ventricular tachycardia had disease of the left anterior descending artery and usually of other coronary arteries as well.

Ventricular tachycardia occurred at the time or before angina developed. When it preceded angina it reduced exercise tolerance. Although ventricular tachycardia was usually unsuspected, retrospective analysis sometimes showed the occurrence of syncope or dizziness on or after exercise. The incidence of ischaemic ventricular tachycardia will vary depending on the population studied and the intensity of diagnostic investigation. Nevertheless, exercise-induced ischaemic ventricular tachycardia is found in fewer than $10^{\circ}{ }_{0}$ of patients with chronic ischaemic heart disease. ${ }^{8} 9$ We think the incidence would be higher if exercise tests were not stopped when certain patterns of ventricular extrasystoles were seen.

Propranolol significantly reduces ventricular extrasystoles on exertion in patients with ischaemic heart disease and may prevent ventricular tachycardia in patients with non-ischaemic ventricular tachycardia. ${ }^{10}$ But beta-blocking agents may not prevent exertional ventricular tachycardia if the exercise heart rate reaches the pretreatment level. Our results show that such treatment in ischaemic heart disease usually increases exercise tolerance but ventricular tachycardia still occurs when the same heart rate is reached. Because beta-blocking drugs and verapamil increase exercise tolerance to angina, they probably increase the duration of exercise needed to produce the same degree of ischaemia.

Studies have shown that neither medical nor surgical treatment for ischaemia always reduces all varieties of ventricular arrhythmias, ${ }^{411}$ but these studies may have diluted serious ventricular arrhythmias with more benign ones. Coronary artery bypass grafting undoubtedly helps some patients with ventricular tachycardia ${ }^{12}{ }^{13}$ and ventricular fibrillation, ${ }^{14}$ but it does so by a different mechanism from that of beta-blocking drugs. Although myocardial infarction may be produced, and thus ablate re-entry circuits or ventricular foci, direct improvement of perfusion is probably responsible. This increases exercise tolerance so that higher heart rates are reached before angina develops. ${ }^{11}$ This is clear from case 1 , in which the exercise toler- ance was increased and yet despite reaching the same heart rate ventricular tachycardia did not occur. A recent study emphasised that after coronary artery bypass surgery exercise tolerance may be so increased that faster heart rates are achieved and ventricular arrhythmias may occur which were not found before surgery. ${ }^{11}$ But the patients included in that study had stopped exercise during their initial tests because of angina; and if angina occurs early in exercise there is a low incidence of ventricular arrhythmias. ${ }^{7}$

A combination of coronary artery bypass surgery and betablocking drugs may be the best form of treatment. Successful coronary artery bypass surgery would increase blood supply, and beta-blocking agents would decrease cardiac work for the same level of exercise. The risk of severe ventricular arrhythmias due to ischaemia should thus be reduced.

Our study was confined to ventricular tachycardia. Ventricular fibrillation after exercise testing has been associated with hypotension. ${ }^{15}$ Further investigation is needed to determine which other ventricular arrhythmias on exercise are dangerous and whether they can be treated successfully. On the evidence there seems no indication to treat ventricular extrasystoles alone. In both our experience and that of others ventricular extrasystoles which occur after exercise or just after the beginning of exercise are usually benign, whereas extrasystoles at peak exercise and those that increase with exercise are usually more dangerous.?

Patients with sustained ventricular tachycardia must be treated. All our patients in group 1 had repeated episodes of tachycardia, but none developed ventricular fibrillation; all had had myocardial infarction and three had aneurysms. This condition is probably different from exercise-induced ventricular tachycardia. It may be due to local fibrosis and re-entry sustaining the tachycardia, although initiation may sometimes be due to ischaemia. After epicardial mapping, aneurysmectomy (possibly with coronary artery surgery) may be needed and may have a beneficial effect on the arrhythmia. ${ }^{16}$

Our experience with repeated exercise tests suggests that exercise-induced ventricular tachycardia is critically rate-related. Ischaemia occurs at a lower heart rate despite prolongation of exercise tolerance on beta-blocking drugs, and yet these ventricular arrhythmias do not occur at these lower heart rates; this also suggests that the heart rate is critically related to the production of these arrhythmias.

The first ventricular extrasystole of tachycardia usually has relatively late coupling (given that the heart rate may be $150 /$ minute) and the rate of ventricular tachycardia is either faster than the peak heart rate or ventricular tachycardia occurs as the heart slows immediately after exercise (fig 2 ). Ventricular fusion
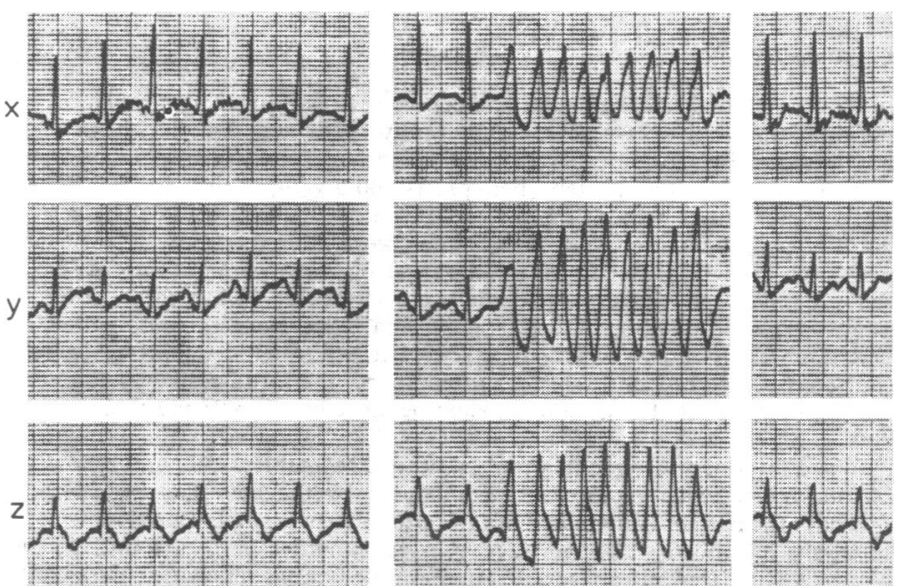

FIG 2-Case 3. Left: orthogonal electrocardiograms recorded just before peak exercise; centre: just after peak exercise ventricular tachycardia occurs and disappears rapidly; right: recording after exercise with reduced tachycardia. 
beats are often seen. These features may be due to enhanced automaticity; not surprisingly, as the heart rate slows and the myocardium becomes less ischaemic, automaticity decreases and the ventricular tachycardia disappears. Re-entry might, however, be the mechanism responsible; fractionation of ventricular depolarisation is increased by cardiac acceleration and thus re-entry ventricular arrhythmias might be produced. When the heart is vulnerable-for example, because of critical coronary artery disease-ventricular fibrillation may be precipitated, but under the conditions of exercise testing immediate resuscitation is at hand. ${ }^{1517}$

Coronary artery bypass surgery is clearly indicated in the presence of severe angina and ventricular arrhythmias and may be justified for persistent ventricular arrhythmias even if betablocking treatment seems to control angina. Case 12 fell into this category although adequate venous grafting was found to be impossible. Antiarrhythmic therapy with quinidine, mexiletine, amiodarone, and disopyramide alone and in combination was unsuccessful in this patient but should be tried first in such circumstances.

There is some evidence that in particular distributions of coronary artery disease death can be prevented by coronary artery bypass surgery-for example, left main stem disease. ${ }^{18}$ If part of this beneficial effect is due to the prevention of lifethreatening ventricular arrhythmias it is imperative to detect clinical features suggesting such arrhythmias. Although ventricular arrhythmias, and particularly the more severe forms, are less reproducible on ambulatory monitoring than on exercise testing, ${ }^{2}$ they are more common on the former, ${ }^{19}$ and ambulatory monitoring and stress testing are complementary. ${ }^{210}$ They disclose ventricular arrhythmias at different times and both must be used to identify such patients at risk.

We are grateful to Professor J F Goodwin and Professor J P w Shillingford for allowing us to publish details of patients under their care.

\section{References}

1 Goldschlager, N, Cake, D, and Cohn, K, American fournal of Cardiology, $1973,31,434$

2 Ryan, M, Lown, B, and Korn, H, New England fournal of Medicine, $1975,292,224$

${ }^{3}$ Raftery, E B, and Cashman, P M, Postgraduate Medical fournal, 1976, 52, suppl No 7, p 32 .

${ }^{4}$ Chiang, B N, et al, Annals of Internal Medicine, 1969, 70, 1159.

5 Bruce, R A, et al, American Heart fournal, 1973, 85, 546.

${ }^{6}$ Judkins, M, Radiology, 1967, 89, 815.

Jelinek, M V, and Lown, B, Progress in Cardiovascular Disease, 1974, 16, 496.

${ }^{8}$ Vedin, J A, et al, American fournal of Cardiology, 1972, 30, 25.

${ }^{9}$ McHenry, P L, et al, American fournal of Cardiology, 1976, 37, 609.

10 Nixon, J V, et al, Circulation, 1978, 57, 115.

11 Tilkian, A G, et al, American Heart fournal, 1976, 92, 707.

${ }^{12}$ Nakhjavan, F K, et al, Journal of the American Medical Association, 1971, 216, 2138.

${ }^{13}$ Ecker, R R, et al, Circulation, 1971, 44, 666.

${ }_{14}$ Cline, R E, Armstrong, R G, and Stanford, W, fournal of Thoracic and Cardiovascular Surgery, 1973, 65, 802.

15 Irving, J B, and Bruce, R A, American fournal of Cardiology, 1977, 39, 849.

16 Gallagher, J J, et al, American fournal of Cardiology, 1975, 35, 696.

17 McHenry, P L, American fournal of Cardiology, 1977, 39, 935.

18 Takaro, T, et al, Circulation, 1976, 54, suppl No 3, p 111.

19 Vismara, L A, et al, American fournal of Cardiology, 1977, 39, 821.

(Accepted 23 fune 1978)

\section{SIDE EFFECTS OF DRUGS}

\section{Diflunisal-induced cholestatic jaundice}

Diflunisal (Dolobid) is a recently introduced analgesic chemically related to aspirin. It has fewer side effects than aspirin but caused a mild increase in the serum concentration of aspartate transaminase (serum AST; SGOT) in one patient. ${ }^{1}$ Jaundice, however, has not been recorded. I report a case of cholestatic jaundice due to diflunisal.

\section{Case report}

A 64-year-old school caretaker had complained of lumbar pain radiating to his right thigh for over a year. Radiography confirmed arthritic changes in the lumbar spine. In February 1978 his symptoms kept him away from work and he was given fenoprofen (Fenopron) $600 \mathrm{mg}$ three times a day. This was supplemented with dextropropoxyphene and paracetamol (Distalgesic) and his symptoms improved. He resumed work after three weeks' absence. In March his symptoms recurred but on this occasion were not improved by fenoprofen and Distalgesic. Indomethacin (Indocid) $25 \mathrm{mg}$ three times a day was therefore substituted for fenoprofen. The dosage of indomethacin was doubled after two weeks in an effort to control his symptoms. After four days on the higher dosage of indomethacin the Distalgesic was stopped and diflunisal started, the indomethacin being reduced to $25 \mathrm{mg}$ three times a day.

The diflunisal was given in an initial dose of two tablets $(500 \mathrm{mg}$ ) followed by one tablet twice a day, as recommended by the manufacturers. After five days the patient complained of mild pruritus, pale stools, and dark urine. His pain had been well controlled. On examination he was found to be clinically jaundiced and apyrexial. There was no lymphadenopathy; chest and heart were normal; the abdomen was soft with no enlargement of gal bladder, liver, or spleen; rectal examination disclosed only pale stools; and urine contained bilirubin. Cholestatic jaundice was diagnosed and diflunisal stopped. He continued to take the indomethacin.

Results of laboratory investigations on the day the diflunisal was stopped were: haemoglobin $15.4 \mathrm{~g} / \mathrm{dl}$; white cell count $6 \times 10^{9} / 1\left(6000 / \mathrm{mm}^{3}\right)$, normal differential; erythrocyte sedimentation rate (ESR) $10 \mathrm{~mm}$ in first hour serum urea and electrolytes normal; total bilirubin $57 \mu \mathrm{mol} / 1(3.3 \mathrm{mg} / 100$ $\mathrm{ml}$ ); alkaline phosphatase $780 \mathrm{IU} / 1$ (normal 120-300 IU/1); and serum AST $120 \mathrm{IU} / 1$ (normal less than $40 \mathrm{IU} / \mathrm{l}$ ). Urine contained a normal amount of urobilinogen; bile salts and bilirubin were detected; a midstream specimen was sterile and contained no excess of cells; and hepatitis B antigen was not detected in the serum. Three days later the serum bilirubin was $71 \mu \mathrm{mol} / 1$ $(4.2 \mathrm{mg} / 100 \mathrm{ml})$, alkaline phosphatase $800 \mathrm{IU} / \mathrm{l}$, and AST $105 \mathrm{IU} / 1$. Four days later the bilirubin was $55 \mu \mathrm{mol} / 1(3.2 \mathrm{mg} / 100 \mathrm{ml})$, and 12 days after the diflunisal was stopped an oral cholecystogram showed a normal functioning gall bladder with no evidence of calculi. A chest radiograph was normal. Neither antimitochondrial antibodies nor smooth-muscle antibodies were detected.

Thirty days after the diflunisal was stopped the serum bilirubin was less than $17 \mu \mathrm{mol} / 1(1.0 \mathrm{mg} / 100 \mathrm{ml})$, alkaline phosphatase $750 \mathrm{IU} / 1$, and AST $50 \mathrm{IU} / 1$. Physical examination showed no enlargement of liver, gall bladder, or spleen, and no other abnormality could be detected. Eighteen days later the haemoglobin was $14.8 \mathrm{~g} / \mathrm{dl}$, ESR $5 \mathrm{~mm}$ in first hour, total bilirubin less than $17 \mu \mathrm{mol} / 1$, alkaline phosphatase $450 \mathrm{IU} / \mathrm{l}$, and serum AST $30 \mathrm{IU} / 1$. Sixty-eight days after stopping diflunisal the serum alkaline phosphatase was $275 \mathrm{IU} / 1$ and AST $20 \mathrm{IU} / 1$. Thus the drug-induced hepatitis had resolved.

\section{Comment}

While this patient was taking diflunisal and indomethacin he developed cholestatic jaundice, and when the diflunisal was stopped and the indomethacin continued the jaundice gradually cleared. $\mathrm{He}$ is still taking indomethacin and Distalgesic.

Indomethacin has been implicated in hepatitis. ${ }^{2}$ Diflunisal may increase plasma concentrations of indomethacin by up to $35 \% .^{3}$ In this case, before the introduction of diflunisal the patient was taking $150 \mathrm{mg}$ of indomethacin daily and when the diflunisal was introduced the dose of indomethacin was halved. Thus it seems highly unlikely that the indomethacin caused the jaundice. It must be concluded that diflunisal was the cause; the time interval from the beginning of the 